Artículo científico

Volumen 30(2):395-405. Mayo-agosto, 2019 e-ISSN 2215-3608, doi:10.15517/am.v30i2.33221 https://revistas.ucr.ac.cr/index.php/agromeso/index

\title{
Effectiveness of arbuscular mycorrhizal fungi inoculated on Canavalia ensiformis L. in Calcaric Histosol soils ${ }^{1}$
}

\section{Efectividad de hongos micorrízicos arbusculares inoculados en Canavalia ensiformis L. en suelos Calcaric Histosol}

\author{
Jaime Enrique Simó-González ${ }^{2}$,Ramón Rivera-Espinosa ${ }^{3}$,Luis Alberto Ruiz-Martínez $z^{2}$,Geysi Díaz Roche², \\ Michael Ruiz-Sánchez
}

1 Recepción: 10 de mayo, 2018. Aceptación: 25 de octubre, 2018. This work was part of a PhD thesis "Integrated management of arbuscular mycorrhizal inoculants, green manure and organic-mineral sources in banana nutrition 'FHIA-18'”, financed by the Fund for Science and Innovation (FONCI, 56-2016), Cuba.

2 Institute of Tropical Tubers Research (INIVIT), Section 3, Santo Domingo, Villa Clara, Cuba. CP 53000. micorrizasf@inivit.cu.

3 National Institute of Agricultural Sciences (INCA), postal drawer 1, San José de las Lajas, Mayabeque, Cuba. CP 32700. rrivera@inca.edu. cu, mich762016@gmail.com (https://orcid.org/0000-0002-7406-471).

\begin{abstract}
Introduction. In recent years, significant results have been obtained in Cuba in the joint management of efficient strains of arbuscular mycorrhizal fungi (AMF) and Canavalia ensiformis L., in different types of soils. However, there are no reports about the effectiveness of strains of AMF in Calcaric Histosol soils, which are highly represented in the central and eastern areas of the country. Objective. The objective of this research was to compare the effectiveness of four AMF strains inoculated in C. ensiformis seeds in in Calcaric Histosol soils. Materials and methods. Plants through seed coatings inoculated and a non-inoculated control were evaluated; C. ensiformis L. was used as plant host in a complete randomized design with four repetitions per treatment during two consecutive years. Sixty days after $C$. ensiformis seeding, the biomass production; $\mathrm{N}, \mathrm{P}$ and $\mathrm{K}$ contents; percentage of total mycorrhizal colonization; and the reproduction of mycorrhizal spores were evaluated. Results. For all variables, there was a positive and differentiated response between the different strains, and the highest values $(\mathrm{p} \leq 0.05)$ were obtained with the inoculation of Rhizoglomus intraradices / INCAM-11. The high amounts of spores produced by the inoculation with R. intraradices / INCAM-11 were indicative of to the possibilities of using Jackbean as a way to introduce efficient strains in this edaphic condition. Conclusion. The results obtained allow to include Calcaric Histosol soils, with $\mathrm{pH}>7.5$, in the group of soils in which $R$. intraradices / INCAM-11 behaves as an efficient strain.
\end{abstract}

Keywords: symbios, green manures, seed inoculation, soil.

\section{Resumen}

Introducción. En los últimos años se han obtenido en Cuba importantes resultados sobre el manejo conjunto de cepas eficientes de hongos micorrízicos arbusculares (HMA) y Canavalia ensiformis L., en diferentes tipos de suelos; sin embargo, no existen reportes sobre la efectividad de cepas de HMA en suelos Calcaric Histosol, los cuales se 
encuentran altamente representados en las zonas central y oriental del país. Objetivo. El objetivo de esta investigación fue comparar la efectividad de cuatro cepas de HMA inoculadas en semillas de C. ensiformis L., en suelos Calcaric Histosol. Materiales y métodos. Se evaluaron plantas inoculadas a través de recubrimientos de semillas y un control no inoculado, se empleó como hospedero vegetal $C$. ensiformis L., en un diseño completamente aleatorizado con cuatro repeticiones por tratamiento durante dos años consecutivos. A los sesenta días de la siembra de C. ensiformis, se evaluaron la producción de biomasa, contenidos de N, P y K, porcentaje de colonización micorrízica total y reproducción de esporas micorrízicas. Resultados. Para todas las variables hubo una respuesta positiva y diferenciada entre las diferentes cepas y siempre los mayores valores $(\mathrm{p} \leq 0,05)$ fueron obtenidos con la inoculación de Rhizoglomus intraradices / INCAM-11. Las altas cantidades de esporas producidas por la inoculación con $R$. intraradices / INCAM-11 fueron indicativas de las posibilidades de utilizar Canavalia como vía para introducir las cepas eficientes en esta condición edáfica. Conclusión. Los resultados obtenidos permiten incluir a los suelos Calcaric Histosol, con $\mathrm{pH}>7,5$, en el grupo de suelos en los que $R$. intraradices / INCAM-11 se comporta como una cepa eficiente.

Palabras claves: simbiosis, abonos verdes, inoculación de semillas, suelo.

\section{Introduction}

Mycorrhizal arbuscular symbiosis is widespred in most economically important crops, and approximately $80 \%$ of plant species establish this type of symbiosis (van-der-Heidjen et al., 2015). Within the ecosystems, this type of symbiosis is recognized as an adaptation mechanism; it increases the plant's capacity to absorb nutrients and water, reduces pathogenic damages, and improving soil aggregates among other effects (Hamel and Strullu, 2006; Pozo and Azcón-Aguilar, 2007; Willis et al., 2013; Yang et al., 2014; Bagyara et al., 2015). However, it is a current challenge to achieve the proper management of this symbiosis through the inoculation of efficient strains in agricultural production.

In recent years, positive results have been obtained by the inoculation of efficient strains of arbuscular mycorrhizal fungi (AMF) in different crops and soil types in Cuba (Rivera et al., 2015). The integration of AMF in nutrient supply schemes, whether in mineral or organic-mineral fertilizers, has led to decrease in the quantities used, maintaining high yields and adequate nutritional status (Rivera et al., 2007; González et al., 2015; Ruiz-Sánchez et al., 2016).

The use of inoculated green manures, specifically Canavalia ensiformis L. (jackbean), in nutrient supply schemes has been successful in recent studies (Martín et al., 2013, Simó et al., 2016), its benefits have been associated not only with the incorporation and recycling of nutrients present in the biomass, but also with the effective mycorrhizal symbiosis present in inoculated Jackbean, which significantly increases mycorrhizal propagules in the soil, and behaves as an effective and economic way to mycorrhizal economic crops in succession.

The basis of the positive effect of permanence of the inoculant applied to the green manure is the generalist character of the strains of AMF used with the plant species, which means that an efficient strain for a given edaphic condition establishes an effective symbiosis with any crop dependent on arbuscular mycorrhization (Rivera et al., 2007). This effect also adds value to the use of green manures in agricultural production.

Although the importance of the soil environment and its $\mathrm{pH}$ have been established in the effectiveness of inoculation of AMF strains in different types of soils (Rivera et al., 2015), and several works have been developed in Jackbean as host (Martín et al., 2015, García et al., 2017), there are no previous reports that compare the efficiency of these strains when inoculated with crops in Calcaric Histosol soils of agricultural importance, with $\mathrm{pH}>7,5 \mathrm{that}$ abound in the central and eastern regions of Cuba. Therefore, as part of the promotion of the joint use of mycorrhizal inoculants and Jackbean in Cuban agriculture, this work was developed with the objective of comparing the effectiveness of four strains of AMF inoculated in C. ensiformis seeds in Calcaric Histosol soils. 


\section{Materials and methods}

The experiment was carried out between May and June of 2012 and 2013 with C. ensiformis L. and AMF in microplots located in the Department of Plant Science of the Instituto de Investigación de Cultivos de Raíces y Tubérculos Tropicales (INIVIT), located at $22^{\circ} 35^{\prime} \mathrm{N}, 80^{\circ} 18^{\prime} \mathrm{W}$ and 40 m.a.s.l., in the municipality of Santo Domingo, province of Villa Clara province, Cuba.

The dimensions of each microplots was $1 \mathrm{~m}^{2}$ by $0.60 \mathrm{~m}$ deep and were filled with Calcaric Histosol soil (WRB, 2014) from the INIVIT field \# 20 and the 0-20 cm deep arable layer. The methodologies described by Paneque et al. (2010) were used for the characterization of agrochemicals (Table 1), the total content of mycorrhizal spore was measured by the wet sieving and decanting method according to Herrera et al. (1995).

Table 1. Agrochemical characteristics and initial spore content in the Calcaric Histosol soil (0-20 cm deep). Santo Domingo, province of Villa Clara, Cuba. 2012.

Cuadro 1. Características agroquímicas y contenido inicial de esporas en el suelo Calcaric Histosol (0-20 cm de profundidad). Santo Domingo, provincia de Villa Clara, Cuba. 2012.

\begin{tabular}{|c|c|c|c|c|c|c|c|c|}
\hline \multirow[t]{2}{*}{ Year } & \multicolumn{2}{|c|}{ pH } & \multirow[t]{2}{*}{ OM g kg-1 } & \multirow{2}{*}{$\begin{array}{c}\mathrm{P}_{2} \mathrm{O}_{5} \\
\mathrm{mg} \mathrm{kg}^{-1}\end{array}$} & $\mathbf{C a}^{2+}$ & $\mathbf{M g}^{2+}$ & $\mathbf{K}^{+}$ & \multirow{2}{*}{$\begin{array}{c}\text { Spore content } \\
\text { (spores in } 50 \mathrm{~g} \text { soil })\end{array}$} \\
\hline & KCl & $\mathrm{H}_{2} \mathrm{O}$ & & & & $\mathrm{mol}_{\mathrm{c}} \mathrm{k}$ & & \\
\hline 2012 & 6.90 & 7.90 & 20.77 & 31.4 & 44.61 & 3.21 & 0.49 & 61.0 \\
\hline 2013 & 6.90 & 7.80 & 21.77 & 32.4 & 45.15 & 3.25 & 0.51 & 43.0 \\
\hline
\end{tabular}

$\mathrm{pH}$ in $\mathrm{H}_{2} \mathrm{O}$ and $\mathrm{KCl}(\mathrm{KCl}$ solution $1 \mathrm{M})$ in soil: solution relation $(1: 2.5)$ by the potentiometric method. Determination of organic matter $(\mathrm{OM})$ level by the Walkley-Black method (oxidation of $\mathrm{C}$ with $\mathrm{K}_{2} \mathrm{Cr}_{2} \mathrm{O} 70.5 \mathrm{M}^{2} \mathrm{H}_{2} \mathrm{SO}_{4} 18 \mathrm{M}$ at $98 \%$ ) and estimation with a solution of $0.25 \mathrm{M}$ of ammonium iron sulphate. Extraction of $\mathrm{P}$ with extractive solution of $\left(\mathrm{NH}_{4}\right)_{2} \mathrm{CO}_{3}$ with a concentration of $10 \mathrm{~g} \mathrm{l}^{-1} \mathrm{pH} 9.0$, and estimation with $\mathrm{HCl} 0.05 \mathrm{M}$ and methyl orange indicator. Extraction of exchangeable cations with $\mathrm{NHAc} 1 \mathrm{M}$ and pH 7 in soil: solution relation of 1:5 and shaking for $5 \mathrm{~min}$ according to the Handbook of analytical techniques for soil and foliar analyses, organic manure and chemical fertilizers" (Paneque et al., 2010) / $\mathrm{pH}$ en $\mathrm{H}_{2} \mathrm{O}$ y $\mathrm{KCl}$ (solución de $\mathrm{KCl} 1 \mathrm{M}$ ) en la relación suelo : solución (1:2,5) por el método potenciométrico. Determinación del nivel de materia orgánica por el método de Walkley-Black (oxidación de $\mathrm{C}_{\text {con }} \mathrm{K}_{2} \mathrm{Cr}_{2} \mathrm{O} 7$ $0,5 \mathrm{M}$ en $\mathrm{H}_{2} \mathrm{SO}_{4} 18 \mathrm{M}$ al $98 \%$ ) y estimación con una solución de $0,25 \mathrm{M}$ de sulfato de hierro amónico. Extracción de P con solución extractiva de $\left(\mathrm{NH}_{4}\right)_{2} \mathrm{CO}_{3}$ con una concentración de $10 \mathrm{~g} \mathrm{l}^{-1}, \mathrm{pH}$ 9,0 y estimación con $\mathrm{HCl}$ 0,05 M e indicador de metil naranja. Extracción de cationes intercambiables con $\mathrm{NH}_{4} \mathrm{Ac} 1 \mathrm{M}$ y pH 7 en la relación suelo: solución de 1:5 y agitación durante 5 min según el Manual de técnicas analíticas para análisis de suelos y foliares, abono orgánico y fertilizantes químicos (Paneque et al., 2010).

According to soil analysis, it showed a slightly alkaline $\mathrm{pH}$, with high concentrations of exchangeable $\mathrm{Ca}^{2+}$, available phosphorus, as well as medium contents of interchangeable $\mathrm{K}^{+}$and $\mathrm{Mg}^{2+}$, and low organic matter, the latter possibly related to degradation processes by the continuous cultivation. The contents of mycorrhizal spores were low and possibly due continuous systematic cultivation in the presence of high doses of mineral fertilizers.

Monthly precipitation and average temperatures in the experimental area (Table 2) were adequate for the Jackbean growth, with the precipitation slightly above the historical average.

Five treatments were studied, consisting of simple inoculation of Jackbean seeds, with four strains of AMF, and a non-inoculated control. A completely randomized experimental design was used with three replicates, with a factorial arrangement of $5 \times 2$ and considering the year as a second factor.

The AMF species used belonged to the collection of the Instituto Nacional de Ciencias Agrícolas (INCA) and corresponded to the following: Funneliformis mosseae / INCAM-2 (Schüßler and Walker, 2011); Glomus cubense / INCAM-4 (Rodríguez et al., 2011); Claroideoglomus claroideum / INCAM-8 (Schüßler and Walker, 2011), and Rhizoglomus intraradices / INCAM-11 (Sieverding et al., 2014). The inoculants were produced in solid formulation 
Table 2. Climatic characteristics of the experimental period in the Instituto de Investigación de Cultivos de Raíces y Tubérculos Tropicales (INIVIT), in Santo Domingo, province of Villa Clara, Cuba, years 2012-2013.

Cuadro 2. Características climáticas del período experimental en el Instituto de Investigación de Cultivos de Raíces y Tubérculos Tropicales (INIVIT), en Santo Domingo, provincia de Villa Clara, Cuba, años 2012-2013.

\begin{tabular}{|c|c|c|c|c|c|c|}
\hline \multirow{2}{*}{$\begin{array}{c}\text { Year } \\
\text { Month }\end{array}$} & \multicolumn{2}{|c|}{2012} & \multicolumn{2}{|c|}{2013} & \multicolumn{2}{|c|}{$\begin{array}{c}\text { Historical average } \\
1978-2013\end{array}$} \\
\hline & $(\mathrm{mm})$ & $\left({ }^{\circ} \mathrm{C}\right)$ & $(\mathrm{mm})$ & $\left({ }^{\circ} \mathrm{C}\right)$ & $(\mathrm{mm})$ & $\left({ }^{\circ} \mathrm{C}\right)$ \\
\hline May & 277.6 & 25.4 & 269.6 & 25.1 & 169.7 & 25.3 \\
\hline June & 226.0 & 26.4 & 149.3 & 26.8 & 207.6 & 26.6 \\
\hline July & 170.0 & 26.5 & 172.1 & 26.5 & 160.9 & 26.5 \\
\hline
\end{tabular}

Source: The data of the climatological variables corresponding to the experimental period and the historical ones of 32 years were taken from the Agrometeorological Station No. 326/INSMET and located in the INIVIT itself. mm: monthly accumulated precipitation; ${ }^{\circ} \mathrm{C}$ : average temperature / Fuente: Los datos de las variables climatológicas correspondientes al período experimental y los históricos de 32 años se tomaron de la Estación Agrometeorológica No. 326/INSMET y ubicada en el propio INIVIT. mm: precipitación acumuladas; ${ }^{\circ} \mathrm{C}$ : temperatura media.

according to Fernández et al. (2000), using Urochloa decumbens Stapf as a plant host and whose spore content ranged between 25 to $30 \mathrm{~g}^{-1}$ of the product.

Ten Jackbean seeds were sown in each microplot with a sowing distance of $0.5 \mathrm{~m}$ between rows and $0.2 \mathrm{~m}$ between plants. Mycorrhizal inoculation was carried out by covering the seeds at $8 \%$ (inoculant / seed) and using $100 \mathrm{ml}$ of water per $\mathrm{kg}$ of inoculant (Simó et al., 2016). Sixty days after germination, the content of mycorrhizal spores in the Jackbean rhizosphere, the percentage of total mycorrhizal colonization, as well as the aerial biomass of the plants, and the concentration of $\mathrm{N}, \mathrm{P}$ and $\mathrm{K}$ were evaluated.

The methodologies used in the different determinations and evaluations were:

\section{Number of spores in the soil}

In each microplot spore extraction was performed following the procedure described by Herrera et al. (1995), they were counted using a stereoscope and the content was expressed as spores per $50 \mathrm{~g}$ of soil.

\section{Total percentage of mycorrhizal colonization}

To determine the total percentage of mycorrhizal colonization in $C$. ensiformis, each microplot was sampling and $200 \mathrm{mg}$ of fine roots from each sample were used and dried in a thermostatically controlled oven, with forced ventilation at $70{ }^{\circ} \mathrm{C}$ at constant mass. The roots were stained according to the methodology described by Rodríguez et al. (2015). The evaluation was made under a stereoscope. For the quantification the method of Giovanetti and Mosse interceptions (1980) was used.

\section{Aerial dry biomass (ADB)}

To determine the aerial dry biomass content, all the plants in each microplot were harvested, then the leaves and stems were separated. The dry mass (DM) in each sample was obtained from the percentage of dry mass of the aerial tissue, resulting from drying each sample in a thermostatically controlled stove, with forced ventilation at $70{ }^{\circ} \mathrm{C}$, until reaching a constant mass, the values were expressed in $\mathrm{g} \mathrm{m}^{-2}$. The quantities of leaves and stems from each plot were added together and expressed in g per microplot. 


\section{Concentration of $\mathbf{N}, \mathbf{P}$ and $\mathrm{K}$}

The concentration of N, P and $\mathrm{K}$ was obtained from tissue samples of dry sprouts, which were subjected to wet digestion with $\mathrm{H}_{2} \mathrm{SO}_{4}+\mathrm{Se}$ (Kjeldahl method), the result was expressed in $\mathrm{mg} \mathrm{g}^{-1}$. Nessler's method was used to determine N, aminonaphthol sulfonic acid for P and flame photometry for K (Paneque et al., 2010).

\section{Estimated extraction of $\mathrm{N}, \mathrm{P}_{2} \mathrm{O}_{5}$ and $\mathrm{K}_{2} \mathrm{O}$}

The $\mathrm{N}, \mathrm{P}_{2} \mathrm{O}_{5}$, and $\mathrm{K}_{2} \mathrm{O}$ extracted $\left(\mathrm{g} \mathrm{m}^{-2}\right)$ were determined as the concentrations of the elements $\left(\mathrm{g} \mathrm{kg}^{-1}\right)$ and the dry mass $(\mathrm{g})$ in each organ studied, it was calculated by the following formula:

Extraction $=$ MS x element concentration $x$ gravimetric factor $\left(1.2\right.$ for $\mathrm{K}_{2} \mathrm{O}$ and 2.29 for $\mathrm{P}_{2} \mathrm{O}_{5}$ ).

The quantities corresponding to leaves and stems in each plot were summed and expressed in $\mathrm{g}$ per microplot.

\section{Statistical procedure}

Once the assumptions of normality and homogeneity of variance of the data were verified, the results to determine the effectiveness of the mycorrhizal inoculation were processed as a completely randomized design with a factorial arrangement of $5 \times 2$. The factors and their respective levels were: AMF strains (four strains and one uninoculated control) and years (two). Tukey's multiple range test $(\mathrm{p} \leq 0.05)$ was used as comparison criterion.

A regression analysis was performed to determinate the degree of mycorrhizal function obtained in each treatment, using the information obtained during the two years of work on the percentage of colonization, dry mass production, concentrations of $\mathrm{N}, \mathrm{P}$ and $\mathrm{K}$ and number of mycorrhizal spores.

\section{Results}

Factorial analysis of all variables showed that there was no significant interaction between the main factors (AMF strains and years). The influence of AMF strains and years factors were significant. The results of the AMF strains factor are presented as they respond directly to the objectives of the work.

Mycorrhizal inoculation had a positive effect $(\mathrm{p} \leq 0.05)$ on the Jackbean biomass production, NPK contents and primary macronutrients extraction (Table 3$)$ with a differentiated response $(\mathrm{p} \leq 0.05)$ between AMF strains. The plants inoculated with $R$. intraradices / INCAM-11 recorded the highest concentrations and extractions of biomass and nutrients with significant differences $(\mathrm{p} \leq 0,05)$ with respect to the rest of the treatments.

Of the remaining species, inoculation with G. cubense / INCAM-4 also had a positive effect with significant differences $(\mathrm{p} \leq 0.05)$ compared to the other species, except for the $\mathrm{N}$ content in which it did not differ from those obtained by the inoculation of G. claraideum / INCAM-8. The inoculation with the F. mosseae / INCAM-2 strain showed a much lower behavior than the other, with values similar to the control treatment.

Likewise, a significant $(\mathrm{p} \leq 0.05)$ and a varied effect of inoculation with AMF strains on mycorrhizal colonization percentages and spore content was found (Table 4), the highest values were always obtained with the inoculation of $R$. intraradices / INCAM-11 strain, with total mycorrhizal colonization percentages higher than $60 \%$ and a 5.5-fold increase in spore content in the crop rhizosphere with respect to non-inoculated control. The rest of the strains presented a behavior similar to that obtained in the variables of biomass and macronutrient content.

In general, the following behavior was obtained with respect to the response or efficacy of the AMF strains studied in each of the evaluated variables: $R$. intraradices / INCAM11 > G. cubense / INCAM4 > C. claroideum / INCAM8 $>$ F. mosseae $/$ INCAM2 $=$ control. 
Table 3. Effect of the inoculation with four strains of arbuscular mycorrhizal fungi on biomass production, concentration, and extraction of macronutrient by C. ensiformis L. sixty days after sowing in each microplot. Calcaric Histosol soil of Santo Domingo, province of Villa Clara, Cuba, years 2012-2013.

Tabla 3. Efecto de la inoculación con cuatro cepas de hongos micorrízicos arbusculares sobre la producción de biomasa, la concentración y la extracción de macronutrimentos por C. ensiformis L. a los sesenta días de la siembra en cada microparcela. Suelo Calcaric Histosol de Santo Domingo, provincia de Villa Clara, Cuba, años 2012-2013.

\begin{tabular}{lccccccc}
\hline Treatment & $\mathbf{A B}$ & \multicolumn{3}{c}{ Concentration $\left(\mathbf{g ~ k g}^{-1}\right)$} & \multicolumn{3}{c}{ Extraction $\left(\mathbf{g} \mathbf{~ m}^{-2}\right)$} \\
\cline { 3 - 8 } & $\left(\mathbf{g ~ m ~}^{-2}\right)$ & $\mathbf{N}$ & $\mathbf{P}$ & $\mathbf{K}$ & $\mathbf{N}$ & $\mathbf{P}_{2} \mathbf{O}_{5}$ & $\mathbf{K}_{2} \mathbf{O}$ \\
\hline Control & $3.28 \mathrm{~d}$ & $21.6 \mathrm{c}$ & $1.45 \mathrm{e}$ & $15.2 \mathrm{~d}$ & $70.9 \mathrm{~d}$ & $10.9 \mathrm{~d}$ & $114.3 \mathrm{~d}$ \\
F. mosseae (INCAM-2) & $3.35 \mathrm{~d}$ & $21.8 \mathrm{c}$ & $1.57 \mathrm{~d}$ & $15.4 \mathrm{~d}$ & $73.0 \mathrm{~d}$ & $11.9 \mathrm{~d}$ & $121.5 \mathrm{~d}$ \\
C. claroideum (INCAM-8) & $4.33 \mathrm{c}$ & $22.7 \mathrm{~b}$ & $1.73 \mathrm{c}$ & $16.3 \mathrm{c}$ & $97.8 \mathrm{c}$ & $17.2 \mathrm{c}$ & $160.9 \mathrm{c}$ \\
G. cubense (INCAM-4) & $5.32 \mathrm{~b}$ & $23.1 \mathrm{~b}$ & $1.87 \mathrm{~b}$ & $16.8 \mathrm{~b}$ & $123.1 \mathrm{~b}$ & $22.4 \mathrm{~b}$ & $205.2 \mathrm{~b}$ \\
R. intraradices (INCAM-11) & $6.02 \mathrm{a}$ & $24.8 \mathrm{a}$ & $1.97 \mathrm{a}$ & $17.7 \mathrm{a}$ & $149.2 \mathrm{a}$ & $26.9 \mathrm{a}$ & $244.2 \mathrm{a}$ \\
$S_{x^{-}}=$ & $0.06^{* *}$ & $0.19^{* *}$ & $0.02^{* *}$ & $0.10^{* *}$ & $1.68^{* *}$ & $0.32^{* *}$ & $2.90^{* *}$ \\
\hline
\end{tabular}

$* *(p<0.01)$ meaning of the ANOVA. The different letters in each column express differences $(\mathrm{p} \leq 0.05)$ according to Tukey’s test. AB: aerial dry biomass $/ * *(\mathrm{p}<0,01)$ significancia del ANOVA. Las diferentes letras en cada columna expresan diferencias ( $\mathrm{p} \leq 0,05)$ según la prueba de Tukey. $\mathrm{AB}=$ biomasa seca aérea.

Table 4. Inoculation effect with four strains of arbuscular mycorrhizal fungi on the total mycorrhizal colonization, and the spore content in the Jackbean rhizosphere at sixty days of sowing. Calcaric Histosol soil of Santo Domingo, province of Villa Clara, Cuba, years 2012-2013

Tabla 4. Efecto de la inoculación con cuatro cepas de hongos micorrízicos arbusculares en la colonización micorrízica total y el contenido de esporas en la rizosfera de Canavalia a los sesenta días de la siembra. Suelo Calcaric Histosol de Santo Domingo, provincia de Villa Clara, Cuba, años 2012-2013.

\begin{tabular}{lcc}
\hline Treatment & Colonization (\%) & $\begin{array}{c}\text { Counting of spores } \\
\text { (spores in 50 g soil) }\end{array}$ \\
\hline Control & $13.67 \mathrm{e}$ & $101.33 \mathrm{~d}$ \\
F. mosseae (INCAM-2) & $19.67 \mathrm{~d}$ & $109.00 \mathrm{~d}$ \\
C. claroideum (INCAM-8) & $30.17 \mathrm{c}$ & $230.33 \mathrm{c}$ \\
G. cubense. (INCAM-4) & $46.33 \mathrm{~b}$ & $309.00 \mathrm{~b}$ \\
R. intraradices (INCAM-11) & $61.67 \mathrm{a}$ & $564.50 \mathrm{a}$ \\
$S_{x^{-}}=$ & $0.43^{* *}$ & $13.41 * *$ \\
\hline
\end{tabular}

$* *(\mathrm{p}<0.01)$ meaning of the ANOVA. The different letters in each column express differences $(\mathrm{p} \leq 0.05)$ according to Tukey's test $/ * *$ $(\mathrm{p}<0.01)$ significancia del ANOVA. Diferentes letras en cada columna expresan diferencias $(\mathrm{p} \leq 0.05)$ de acuerdo con la prueba de Tukey.

Not only the inoculation with the $R$. intraradices / INCAM-11 strain reached the highest response in all evaluated variables, but high and significant determination coefficients were established, in the different treatments, between the percentages of total mycorrhizal colonization and the rest of the variables (Figure 1).

The scatter plots and mathematical functions found for biomass (Figure 1A), P concentration (Figure 1C) and $\mathrm{K}$ concentration (Figure 1D), it seems to show a stabilization of the variables with the highest colonization; 

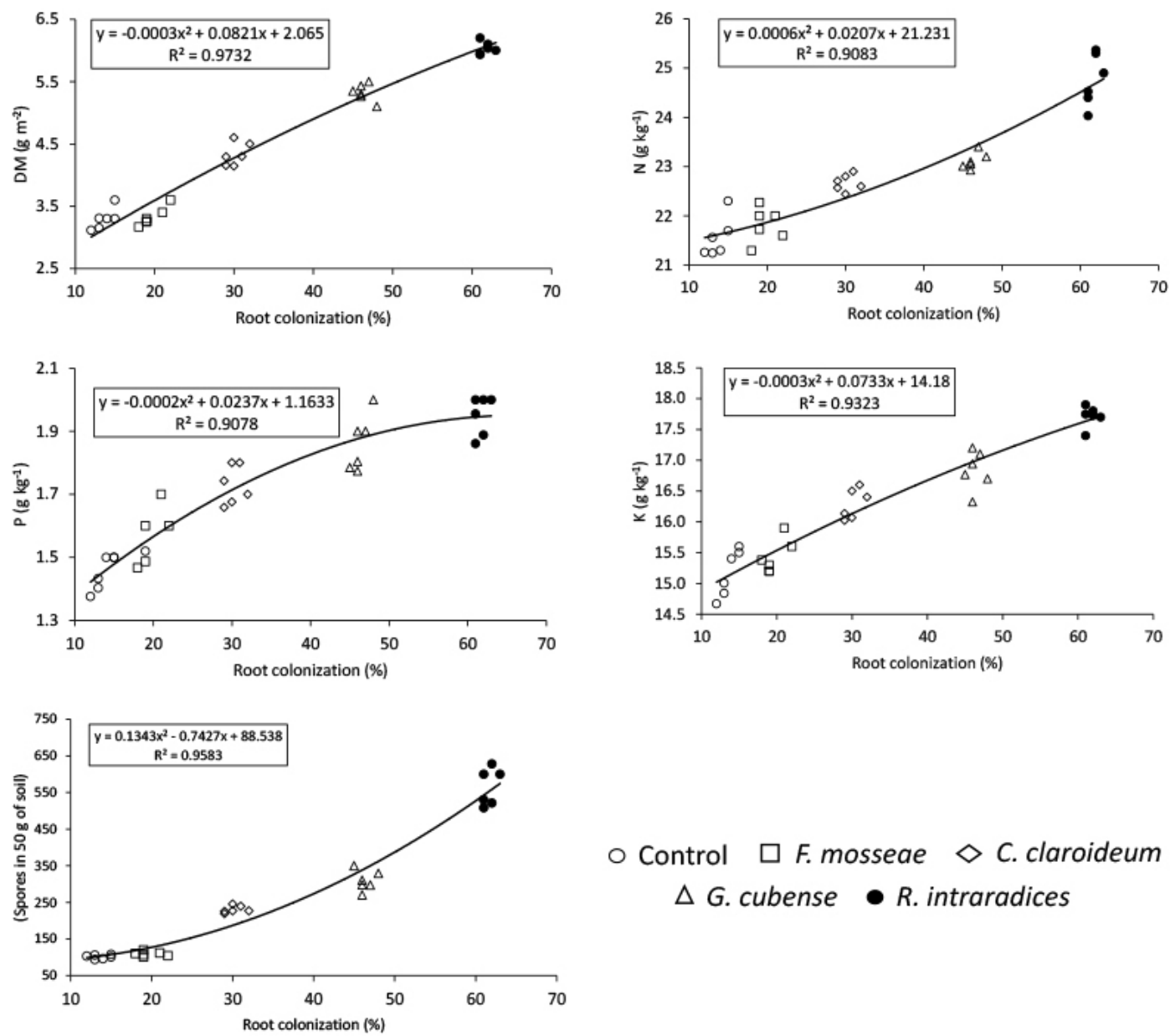

\section{- Control $\square$ F. mosseae $\diamond$ C. claroideum}

$\Delta$ G. cubense $\bullet$ R. intraradices

Figure 1. Relationships between the percentages of mycorrhizal colonization with the production of biomass (A); the contents of $\mathrm{N}$ (B), P (C), K (D); and with the number of mycorrhizal spores reproduced (E) in a Calcaric Histosol soil of Santo Domingo, province of Villa Clara, Cuba, years 2012-2013.

Figura 1. Relaciones entre los porcentajes de colonización micorrízica con la producción de biomasa (A), los contenidos de N (B), P (C), K (D) y con el número de esporas de micorrizas reproducidas (E), en un suelo Calcaric Histosol de Santo Domingo, provincia de Villa Clara, Cuba, años 2012-2013.

however, spores production (Figure 1E) and N content (Figure 1B) it seems to show a different behavior, since they did not suggest a stabilization, but an incremental increase with the highest values of mycorrhizal colonization.

\section{Discussion}

The positive effect of the inoculation with $R$. intraradices / INCAM-11 on the biomass and nutritional contents of Jackbean was explained by the establishment of an effective arbuscular mycorrhizal symbiosis and its beneficial effects on nutrient uptake (Willis et al., 2013; Yang et al., 2014) and thus on crop biomass production. The percentage of mycorrhizal colonization found in treatments with $R$. intraradices was around $60 \%$, a result that 
has been indicative of an efficient mycorrhizal functioning in most crops (Rivera et al., 2007) and in the Canavalia itself (Martín et al., 2015; García et al., 2017). Several Cuban authors have reported similar effects on mycorrhizal functioning, nutritional status and yields by inoculating different crops with efficient strains of AMF in different types of soils (Ruiz et al., 2012; González et al., 2015; Simó et al., 2016). Specifically, positive results have been reported for inoculation of the $R$. intraradices / INCAM-11 strain in different crops, such as grasses, bananas, Jackbean, cassava, rice, beans, among others, and types of soils and substrates, provided that the $\mathrm{pH}$ of these, in the depth of the soil in which the roots grow, is greater than seven (Rivera et al., 2015; González et al., 2016; João et al., 2016; Ruiz-Sánchez et al., 2016; Simó-González et al., 2017). The order of effectiveness of the different strains found in this work was also similar to that reported by previous authors in soils with light alkalinity conditions $(\mathrm{pH}$ between 7 and 8), suggesting that the strains respond differently and reproducibly to soil conditions.

Whit the inoculation of the F. mosseae / INCAM-2 strain there was no positive response, similar to that found in different crops in soils with $\mathrm{pH} \geq 7.4$ (Göransson et al., 2008; González et al., 2016). Therefore, it appears that in the Calcaric Histosol soils whose soil reaction will always be higher than $\mathrm{pH}>7.5$ the criteria obtained between the efficacy of the evaluated AMF strains and the soil $\mathrm{pH}$ are also met (Rivera et al., 2015), with $R$. intraradices / INCAM-11 being an efficient AMF strain in these soil conditions.

To control the distribution and consequent adaptation of the resident AMF species in agroecosystems, several authors (Göransson et al., 2008; Oehl et al., 2010) have pointed out the importance of soil and pH, these reports did not include inoculation of AMF strain and therefore could not evaluate the influence of $\mathrm{pH}$ on the efficacy of these strains.

The high values of mycorrhizal spores produced by the inoculation with $R$. intraradices / INCAM-11, are an indicator of effectiveness of the behavior of this strain under the conditions under study, they are also an indication of the ability of jackbean to reproduce mycorrhizal spores associated with the inoculation of the efficient strain. Similar increases in spore values have been found when inoculating Jackbean with efficient strains of AMF in different soil by Martín et al. (2009), Pentón et al. (2016), and Simó et al. (2016), which also reported a significant effect of permanence of the inoculant applied on the subsequent crop and related this permanence effect to the high reproduction of the spores, although the spores are not the only mycorrhizal propagules under these conditions (Willis et al., 2013).

The high determination coefficients obtained between the percentages of total mycorrhizal colonization and the rest of the variables indicated the importance of mycorrhizal functioning on the nutritional state of Jackbean and biomass production, which suggest that the differences in the effectiveness of the strains were a consequence of the different degrees of colonization reached with each one of them.

The high relationship between the colonization percentages and spore production could be due to the causal relationship between both variables, since the plants are first to be colonized, which causes the appearance of functioning mycorrhizal spores (Willis et al., 2013), but also indicates the importance of the spore number indicator as a criterion for mycorrhizal functioning.

Although some authors have reported that the inoculated strains cause greater growth and percentage of colonization, but these are not the ones that reproduce more spores (Chauhan et al., 2012); other authors (Furralzola et al., 2016) evaluated under natural conditions different species of grasses have not found a direct relationship between the percentages of colonization and spores, which is explained by the different reproductive capacity of the crops (Bever et al., 1996), as well as, possibly, in the different physiological state of them. Another effect occurs when comparing the effects of the inoculation of different generalist strains in the same crop. In several studies carried out in Cuba it has been found that the most effective strains have not only had a greater response in the biomass production and yield, with higher percentages of colonization, but also with more spores per $\mathrm{g}$ of soil (Martín et al., 2009; González, 2014; Martín et al., 2015; Gonzalez et al., 2016; Garcia et al., 2017). This is reinforced by the fact that the number of mycorrhizal spores is considered an adequate indicator to know the extent of the effect of permanence of the inoculant applied in Uroclhoa plantations (González, 2014). 
Although the increases in spore production depends on the percentage of colonization, this is also a consequence of the number of mycorrhizal roots (Rivera et al., 2010; González, 2014). Both variables participate in spore production rate colonization increases. $\mathrm{N}$ content also behaved similarly, but in this case, can be explainable by the increase in biological nitrogen fixation (BNF), and therefore in $\mathrm{N}$ content, associated with the presence of an effective mycorrhizal symbiosis in legumes and a positive interaction between both symbiosis (Chalk et al., 2006; Yasmeen et al., 2012; Bulgarelli et al., 2017).

The different mycorrhizal colonization capacities found in the strains studied appear to be a consequence of the influence of the soil environment and presumably the $\mathrm{pH}$ (Rivera et al., 2015); however, there is no clarity as to the specific mechanism by which these factors influence the effectiveness of the strains.

\section{Conclusions}

Inoculation of Jackbean with the strain R. intraradices / INCAM-11 on Calcaric Histosol showed the greatest effects on biomass production, nutritional status and mycorrhizal function indicators, with higher results than when inoculate with G. cubense / INCAM-4, G. claroideum / INCAM-8 and F. mosseae / INCAM-2.

The high amounts of mycorrhizal spores associated with the inoculation of Canavalia with $R$. intraradices / INCAM-11 in this soil condition were indicative of the possibilities of using inoculated Jackbean as a way of subsequent mycorrhizal culture in this soil type.

\section{Acknowledgement}

To the Fondo Financiero de Ciencia e Innovación (FONCI) of Cuba for the financial support for the realization of this research in the framework of the project FONCI 56-2016.

\section{Cited literature}

Bagyaraj, D.J., M.P. Sharma, and D. Maiti. 2015. Phosphorus nutrition of crops through arbuscular mycorrhizal fungi. Curr. Sci. 108:1288-1293.

Bever, J.D., J.B. Morton, J. Antonovics, and P.A. Schultz. 1996. Host-dependent sporulation and species diversity of arbuscular mycorrhizal fungi in a mown grassland. J. Ecol. 84:71-82. doi:10.2307/2261701

Bulgarelli, R., F. Marcos, R. Ribeiro, and S.A. de-Andrade. 2017. Mycorrhizae enhance nitrogen fixation and photosynthesis in phosphorus-starved soybean (Glycine max L. Merrill). Environ. Exp. Bot. 140:26-33. doi:10.1016/j.envexpbot.2017.05.015

Chalk, P.M., R.F. Souza, S. Urquiaga, B.J.R. Alves, and R.M. Boddey. 2006. The role of arbuscular mycorrhiza in legume symbiotic performance. Soil Biol. Biochem. 38:2944-2951. doi:10.1016/j.soilbio.2006.05.005

Chauhan, H., D.J. Bagyaraj, G. Thilagar, and J.E. Ravi. 2012. Plant growth response of French bean to arbuscular mycorrhizal fungi. J. Soil Biol. Ecol. 32:50-56.

Fernández, F., R. Gómez, L.F. Vanegas, R. Rivera, B.M. Noval, y M.A. Martínez. 2000. Patente No. 22641: Producto inoculante micorrizógeno. Oficina Nacional de Propiedad Industrial, La Habana, CUB.

Furrazola, E., L. Ojeda, and C. Hernández. 2016. Mycorrhizal colonization and species of arbuscular mycorrhizal fungi in grasses from the Cuenca Pecuaria "El Tablón”, Cienfuegos, Cuba. Cub. J. Agric. Sci. 50:321-331. 
García, M., R. Rivera, Y. Cruz, Y. Acosta, y J.R. Cabrera. 2017. Respuesta de Canavalia ensiformis (L.) a la inoculación con diferentes cepas de hongo micorrízico arbuscular en un suelo FARL. Cul. Trop. 38(1):16-21.

Giovanetti, M., and B. Mosse. 1980. An evaluation of techniques for measuring vesicular arbuscular mycorrhizal infection in roots. New Phytol. 84:489-500. doi:10.1111/j.1469-8137.1980.tb04556.x

González, P.J. 2014. Manejo efectivo de la simbiosis micorrízica arbuscular, vía inoculación y la fertilización mineral en pastos del género Brachiaria. Tesis Dr. Instituto Nacional de Ciencias Agrícolas, La Habana, CUB. http://beduniv.reduniv.edu. cu/index. php?page $=13 \& \mathrm{id}=945 \& \mathrm{db}=1$ (consultado abr. 2017).

González, P.J., J.F. Ramírez, R. Rivera, A. Hernández, R. Plana, and G. Crespo. 2015. Management of arbuscular mycorrhizal inoculation for the establishment, maintenance and recovery of grasslands. Cuban J. Agric. Sci. 49:535-540.

González, P.J., J.F. Ramírez, R. Rivera, A. Hernández, y G. Crespo. 2016. Efectividad de la inoculación de hongos micorrízicos arbusculares en dos leguminosas forrajeras cultivadas en dos tipos de suelos. Trop. Grassl. 4:82-90. doi:10.17138/ TGFT(4) $82-90$

Göransson, P., P.A. Olsson, J. Postma, and U. Falkengren-Grerup. 2008. Colonization by arbuscular mycorrhizal and fine endophytic fungi in four woodland grasses-variation in relation to $\mathrm{pH}$ and aluminium. Soil Biol. Biochem. 40:2260-2265. doi:10.1016/j.soilbio.2008.05.002

Herrera, R., R.L. Ferrer, E. Furrazola, y M.O. Orozco. 1995. Estrategia de funcionamiento de las micorrizas VA en un bosque tropical. En: M. Monasterio, editor, Biodiversidad en Iberoamérica. Ecosistemas, evolución y procesos sociales. Programa Iberoamericano de Ciencia y Tecnología para el desarrollo, Mérida, MEX. p. 13.

Hamel, C., and D.G. Strullu. 2006. Arbuscular mycorrhizal fungi in field crop production: Potential and new direction. Can. J. Plant Sci. 86:941-950. doi:10.4141/P05-099

João, J.P., A. Espinosa, L. Ruiz, J. Simó, y R. Rivera. 2016. Efectividad de cepas de AMF en el cultivo de la yuca (Manihot esculenta Crantz) en dos tipos de suelos. Cul. Trop. 37(1):48-56.

Martín, G.M., R. Reyes, y J.F. Ramírez. 2015. Coinoculación de Canavalia ensiformis (L.) D.C. con Rhizobium y hongos micorrízicos arbusculares en dos tipos de suelos de Cuba. Cul. Trop. 36(2):22-29.

Martín, G.M., R. Rivera, L. Arias, y M. Rentería. 2009. Efecto de la Canavalia ensiformis y micorrizas arbusculares en el cultivo del maíz. Rev. Cub. Cienc. Agríc. 43(2):191-195.

Martín, G., R. Rivera, y A. Pérez. 2013. Efecto de canavalia, inoculación micorrízica y dosis de fertilizante nitrogenado en el cultivo del maíz. Cul. Trop. 34(4):60-67.

Oehl, F., E. Laczko, A. Bogenrieder, K. Stahr, R. Bösch, M. van-der-Heijden, and E. Sieverding. 2010. Soil type and land use intensity determine the composition of arbuscular mycorrhizal fungal communities. Soil Biol. Biochem. 42:724-738. doi:10.1016/j.soilbio.2010.01.006

Paneque, P.V., N.J. Calaña, V. Calderón, B. Borges, G.T. Hernández, y C. Caruncho. 2010. Manual de técnicas analíticas para análisis de suelo, foliar, abonos orgánicos y fertilizantes químicos. Ediciones INCA, Mayabeque, CUB.

Pentón, G., G. Martín, y R. Rivera. 2016. Efecto del arreglo espacial y el intercalamiento con Canavalia ensiformis micorrizada en la respuesta agroproductiva de Morus alba. Pastos y Forrajes 39(3):92-99.

Pozo, M.J., and C. Azcón-Aguilar. 2007. Unraveling mycorrhiza-induced resistance. Curr. Opinion Plant Biol. 10:393-398. doi:10.1016/j.pbi.2007.05.004

Rivera, R. 2010. Abonos verdes e inoculación micorrízica de posturas de cafeto sobre suelos Fersialíticos Rojos Lixiviados. Cul. Trop. 31(3):75-81. 
Rivera, R., C. Sánchez, D. Caballero, D. Cupull, C. González, y S. Urquiaga. 2010. Abonos verdes e inoculación micorrízica de posturas de cafeto sobre suelos Fersialíticos Rojos Lixiviados. Cultivos Trop. 31(2):75-81.

Rivera, R., F. Fernández, K. Fernández, L. Ruiz, C. Sánchez, and M. Riera. 2007. Advances in the management of effective arbuscular mycorrhizal symbiosis in tropical ecosystem. In: C. Hamel, and C. Plenchette, editors, Mycorrhizae in crop production. Haworth Press, Binghamton, NY, USA. p. 151-196.

Rivera, R., P.J. González, A. Hernández, G. Martín, L. Ruíz, K. Fernández, J. Simó, M. García, A. Pérez, M. Riera, C. Bustamante, J.P. Joao, y M. Ruiz. 2015. La importancia del ambiente edáfico y del pH sobre la efectividad y la recomendación de cepas eficientes de AMF para la inoculación de los cultivos. En: Sociedad Cubana de la Ciencia del Suelo, editor, Memorias del VIII Congreso de la Sociedad Cubana de la Ciencia del Suelo. Sociedad Cubana de la Ciencia del Suelo, La Habana, CUB. p. 12.

Rodríguez, Y., L. Arias, A. Medina, Y. Mujica, L. Medina, K. Fernández, y A. Mena. 2015. Alternativa de la técnica de tinción para determinar la colonización micorrízica. Cul. Trop. 36(2):18-21.

Rodríguez, Y., Y. Dalpé, S. Séguin, K. Fernández, and R.A. Rivera. 2011. Glomus cubense sp. nov., an arbuscular mycorrhizal fungus from Cuba. Micotaxon 118:337-347. doi:10.5248/118.337

Ruiz, L., J. Simó, S. Rodríguez, y R. Rivera. 2012. Las micorrizas en cultivos tropicales. Una contribución a la sostenibilidad agroalimentaria. Editorial Académica Española, Madrid, ESP.

Ruiz-Sánchez, M., Y. Muñoz-Hernández, J. Dell’Amico-Rodríguez, J. Simó-González, y J.A. CabreraRodríguez. 2016. Evaluación de diferentes cepas de micorrizas arbusculares en el desarrollo de plantas de arroz (Oryza sativa L.) en condiciones inundadas del suelo. Cul. Trop. 37(4):67-75. doi:10.13140/RG.2.2.31096.85761

Schüßler, A., and C. Walker. 2011. Evolution of the 'Plant-Symbiotic' fungal Phyllum, Glomeromycota. In: S. Pöggeler, and J. Wöstemeyer, editors, Evolution of fungi and fungal-like organisms. The mycota (A comprehensive treatise on fungi as experimental systems for basic and applied research). Vol. 14. Springer-Verlag, Berlin-Heidelberg, GER. p. 163-185.

Sieverding, E., G. da-Silva, R. Berndt, and F. Oehl. 2014. Rhizoglomus, a new genus of the Glomeraceae. Mycotaxon 129:373386. doi:10.5248/129.373

Simó, J., R. Rivera, L. Ruiz, y E. Espinosa. 2016. Necesidad de reinoculación micorrízica en el trasplante del banano en áreas con precedente de canavalia inoculada con AMF. Ctro. Agr. 43(2):28-35.

Simó-González, J.E, L.A. Ruiz-Martínez, y R. Rivera-Espinoza. 2017. Inoculación de hongos micorrizógenos arbusculares (HMA) y relaciones suelo Pardo-abonos orgánicos en la aclimatización de vitroplantas de banano. Cul. Trop. 38(3):102-111.

van-der-Heijden, M.G.A., F.M. Martin, M.A. Selosse, and I. Sanders. 2015. Mycorrhizal ecology and evolution: the past, the present, and the future. New Phytol. 205:1406-1423. doi:10.1111/nph.13288.

Willis, A., B.F. Rodrigues, and P.J.C. Harris. 2013. The ecology of arbuscular mycorrhizal fungi. Crit. Rev. Plant Sci. 32:1-20. doi:10.1080/07352689.2012.683375

Yang, W.C., A. Ellouze, A. Navarro-Borrell, T.R. Esmaeili, M. Klabi, Z.K. Dai, and C. Hamel. 2014. Management of the arbuscular mycorrhizal symbiosis. sustainable crop production. In: Z.M. Solaiman et al., editors, Mycorrhizal fungi: Use in sustainable agriculture and land restoration. Springer-Verlag, Berlin-Heidelberg, DEU. p. 89-118. doi:10.1007/978-3-662-45370-4_7

Yasmeen, T., S. Hameed, M. Tariq, and S. Ali. 2012. Significance of arbuscular mycorrhizal and bacterial symbionts in a tripartite association with Vigna radiata. Acta Physiol. Plant. 34:1519-1528. doi:10.1007/s11738-012-0950-x 